\title{
The Effect of Sulfamethoxazole and Selenium on Antioxidant Defense System in the Blood of Rats Treated With DEN
}

\author{
Ritu Gupta*, Firoz Anwar ${ }^{a}$, R.L.Khosa ${ }^{b}$ \\ *Research Scholar Uttarakhand Technical University, Dehradun, 248001 \\ a Siddhartha Institute of Pharmacy, Dobachi, Near IT Park, Dehradun, Uttarkhand, 248001 \\ b BIT, Partapur Bypass, Meerut, U.P., 250103
}

\begin{abstract}
Objective: This study aims to elucidate the combined effect of sulfamethoxazole (SMX) and antioxidant selenium (Se) on hematological parameters and antioxidant system in diethylnitrosamine (DEN) induced toxicity in rats. Materials and Methods: Forty two male albino wistar rats were randomly assigned into seven groups of six rats each. Group 1 was control, while groups 2 (DEN control), group 3 (SMX control), group 4 (Se control), group 5 (SMX + Selenium control), group 6 (THR) and group 7 (PRH), received 30mg/kg sulfamethoxazole hydrochloride, $4 \mathrm{mg} / \mathrm{kg}$ sodium selenite orally and single dose of $150 \mathrm{mg} / \mathrm{kg} D E N$ i.p. for 22 weeks, respectively. Rats in all seven groups received normal rat chow and drinking water ad libitum. Complete blood count was done using an automatic counter.

Results and Discussion: Rats treated with DEN showed severe toxic signs and significant decrease $(P<0.05)$ white blood cell, red blood cell, hemoglobin concentration. However, the mean neutrophils count in the all groups was decreased significantly $(P<0.001)$ except in the animals of group 4. The RBC count of the groups 4 and 6 was significantly higher than that of the animals of groups 2 and $7(P<0.001)$. The antioxident activity of enzymes GST, catalase, GPX and SOD in the animals of group 6 were found to be SMX significant increased but a significant decrease $(\mathrm{P}<0.001)$ in the levels of GSH was observed when compared with DEN treated group. However, co-administration of sulfamethoxazole (SMX) and selenium (Se) had a protective effect on the potential carcinogen DEN.
\end{abstract}

Conclusion: Thus it is concluded that oral administration of sulfamethoxazole and selenium increases $R B C, H b$ concentration, neutrophils and antioxident enzymes in treatment group.

Key words: Antioxident enzymes, Hematological parameter, Sodium selenite, Sulfamethoxazole

\section{I.1. LIVER CANCER}

\section{Introduction}

Liver cancer is the leading cause of death in economically developed countries and the second leading cause of death in developing countries ${ }^{1}$. Hepatocellular carcinoma (HCC) is the most common primary malignancy of the liver. Worldwide, approximately 500,000 new patients are diagnosed with HCC each year, often associated with poor prognosis ${ }^{2}$. Also, it is reported that nearly $77 \%$ of deaths from HCC occur in developing countries. The prognosis of HCC is dismal with 5 -year survival being $1-4 \%^{3}$. The prevalence of $\mathrm{HCC}$ in India varies from 0.2 to $1.6 \%{ }^{4,5}$.

\section{I.2. N-NITROSODIETHYLAMINE (DEN)}

$\mathrm{N}$-nitrosodiethylamine (DEN) is often used as a carcinogenic agent. The oxidative stress caused by DEN can contribute to hepatocarcinogenesis ${ }^{6,7}$. Reactive oxygen species (ROS) generated by the P450dependent enzymatic system might induce oxidative stress by the formation of hydrogen peroxide and superoxide anions. Production of ROS is known to cause DNA, protein and lipid damage; therefore, oxidative stress can play an important role in carcinogenesis ${ }^{8,9}$.

\section{I.3. SULFAMETHOXAZOLE(SMX)}

Sulfamethoxazole being the drug of sulphonamide series acts as a competitive inhibitor of the enzyme dihydropteroate synthease (DHPS) which catalyses the conversion of para-aminobenzoate (PABA) to dihydropteroate (AHHMD), a precursor of folate synthesis necessary for the formation of nucleic acids that are essential as building blocks of RNA or DNA ${ }^{10}$. As a result, it is possible to inhibit the synthesis of nucleic acids and thus proteins. The hydroxylamine and nitroso derivatives of sulfamethoxazole have been implicated in sulfanoamide adverse drug reactions and induce sulfonamide- mediated immunomodulatory effects ${ }^{11,12}$. Sulfonamides inhibit the synthesis of purine nucleotides and nucleic acids, these inhibitors also affects the proliferation of normally growing cells by competitively inhibit dihydrofolate reductase and block the formation of tetrahydrofolate (THF) providing hindrance in the biosynthesis of Purines, Thymine nucleotides and hence DNA is impaired, this result in blockage of cell proliferation. 


\section{I.4. SELINIUM (Se)}

Selenium is an essential trace element in the human body ${ }^{13}$, an important part of the antioxidant enzymes that protect cells against the effects of free radicals that are produced during the normal oxygen metabolism. The body has developed defenses, such as antioxidants, to control the levels of free radicals, which can damage cells and contribute to the development of some chronic diseases ${ }^{14-18}$. These selenoproteins include glutathione peroxidase (GPx) and thioredoxin reductase (TrxR), which have important antioxidant and detoxification functions ${ }^{19}$.

Mechanisms for anticancer action of selenium are not fully understood; however, several theories have been proposed, the important ones being antioxidant protection, enhanced carcinogen detoxification, enhanced immune surveillance, modulation of cell proliferation (cell cycle and apoptosis), inhibition of tumor cell invasion, and inhibition of angiogenesis ${ }^{20,21}$.

\section{II.1. Drugs and Chemicals:}

\section{Materials and Methods}

Selenium, DEN was procured from Sigma-Aldrich Chemicals Co. St. Louis, USA and Sulfamethoxazole hydrochloride was provided as a gift sample from ASOJ pharmaceutilcal limited, Ahmadabad, Gujrat, India Chloroform and Diethyl ether from S.D. Fine Chem. Ltd. Mumbai. Disodium Hydrogen Phosphate was purchased from Merck Specialities Pvt. Ltd. Mumbai. All the chemicals were of analytical grade.

\section{II.2. Animals:}

This experiment was carried out on wistar rats weighing 100-125 g. They were procured from the animal house facility of Siddhartha Institute of Pharmacy for these experiments. Animals were caged in group of six under controlled conditions of temperature $\left(22^{\circ} \mathrm{C}+3{ }^{\circ} \mathrm{C}\right)$ and light $(14: 10 \mathrm{~h}$ light and dark cycle) and provided balanced pallet diet and water ad libitum. The Protocol was approved by the Institutional Animal Ethical Committee (IAEC) (Reg. no. SIP/IAEC/17/2011) as per the guidance of the Committee for the Purpose of Control and Supervision of Experiments on Animals (CPCSEA); Ministry of Social Justice and Empowerment, Government of India and taken for conducting research studies.

\section{II.3. Dose selection of DEN, sulfamethoxazole and sodium selenite for induction and treatment of hepatocarcinogenesis induction}

The doses of DEN, sulphamethoxazole and sodium selenium were selected as per the model reported by Ghosh A.S., ${ }^{22}$ Lawrence D. Mayer et $\mathrm{al}^{23}$ and Alwahaidi et al ${ }^{21}$ respectively.

\section{II.4. Experimental Design}

Experiment animals were divided into7 groups, 6 rats in each group, as follow:

Group 1 (NC): rats were given normal rat chow and drinking water. Also, a single intraperitoneal (i.p) injection of normal saline was given.

Group 2 (DEN): liver tumors were induced with a single I.P injection of DEN at a dose of $150 \mathrm{mg} / \mathrm{kg}$ body weight in normal saline.

Group 3 (SMX): Rats in this group served as a control for group 6 and group 7. Rats were given sulphamethoxazole for 22 weeks orally $(30 \mathrm{mg} / \mathrm{kg}$ ). Instead of DEN, a single i.p. injection of normal saline was given.

Group 4 (Se): Rats in this group served as a control for group 6 and group 7. Rats were given sodium selenite $(4 \mathrm{mg} / \mathrm{kg})$ for 22 weeks. No DEN was given. Instead, a single i.p. injection of normal saline was given.

Group 5 (SMX+Se): Animals in this group designed as a control for group 6 and group 7. Animals were given sodium selenite $(4 \mathrm{mg} / \mathrm{kg})$ and sulphamethoxazole $(30 \mathrm{mg} / \mathrm{kg})$ in combination, orally for 22 consecutive weeks. No DEN was given. Only single i.p. injection of normal saline was given.

Group 6 Therapeutic group (THR): 8 weeks after single dose of DEN administration, the rats were treated with sodium selenite $(4 \mathrm{mg} / \mathrm{kg})$ and sulphamethoxazole $(30 \mathrm{mg} / \mathrm{kg})$ in combination, orally for 22 weeks.

Group 7 Prophylactic group (PRH): 8 weeks before single dose of DEN administration, animals were given sulphamethoxazole + Selenium combination orally, and continued at the end of experiment (22 weeks).

\section{II.5. Record of body weights}

A record of the body weights of normal control, DEN, sulfamethoxazole, selenium, and combination of both treated animals was kept throughout the study. The animals were weighed at the beginning of the experiment, once a week during the experiment and finally before sacrifice. Diet was freshly prepared and wood 
chips for bedding were changed weekly. 22 weeks after the initiation of the experiment; all the rats were fasted overnight and then killed by cervical dislocation under ether anesthesia.

\section{II.6. Sampling and Analysis of biochemical parameters:}

Blood was collected from all groups directly from retro-orbital plexus after anesthetizing the animal with a mixture of chloroform-ether (2:3). Blood samples were collected in EDTA anticoagulant tubes (ethylene diamine tetra-acetic acid $8.5 \%$ ), shake well and labeled and immediately stored in fridge device till it was required to conduct analysis which included - white blood cell count (WBC), red blood cells count (RBC), hemoglobin concentration $(\mathrm{Hg})$, and the lymphocytes. The abdominal cavity of rats was dissected immediately after decapitation and the liver was rapidly removed, washed by ice-cold saline, weighed and blotted dry. A portion of the liver was homogenized in ice-cold saline and stored in defreeze for further use. $1 \%$ homogenate of the liver tissue was prepared in phosphate buffer $(0.1 \mathrm{M} ; \mathrm{pH}$ 7.4), centrifuged, and the clear supernatant using a centrifuge at $1000 \mathrm{rpm}$ for 15 minutes at $4^{0} \mathrm{C}$ to remove the cell debris and the supernatant was used to carry out the biochemical estimations which include lipid peroxidation (LPO), superoxide dismutase (SOD), catalase (CAT), glutathione peroxidase (GPx), and glutathione transferase (GST) ${ }^{24}$. However, hemoglobin, TLC, neutrophils, lymphocyte and RBCs was estimated using a standard kit (Nicholas India Pvt. Ltd.) with semi-auto analyzer (photometer 5010, Nicholas India Pvt. Ltd).

\section{II.7. Lipid peroxidation and antioxidant defense system enzymes}

Lipid peroxidation was assayed according to the method of Wills ${ }^{25}$. One of the end products of lipid peroxidation is malondialdehyde (MDA), which forms a pink colored complex with thiobarbituric acid with absorption maxima at $532 \mathrm{~nm}$. Glutathione-Peroxidase enzyme activity was assayed using glutathione reductase and $\mathrm{H}_{2} \mathrm{O}_{2}$ as substrates, and the optical density was read at $340 \mathrm{~nm}$ with a double beam spectrophotometer ${ }^{26}$. The activity of total SOD was measured at $560 \mathrm{~nm}$ following the method of Kono ${ }^{27}$. The enzymatic determination of catalase was performed according to the method of Luck ${ }^{28}$ and the concentration of $\mathrm{H}_{2} \mathrm{O}_{2}$ was monitored at $240 \mathrm{~nm}$. The activity of glutathione-S-transferase was estimated according to the method of Habig et al ${ }^{29}$. Reduced GSH contents were determined using the method of Ellman ${ }^{30}$. Glutathione reductase (GR) activity was assayed using the method of Carlberg et $\mathrm{al}^{31}$.

\section{II.8. Statistical Analysis:}

The results were expressed as Mean \pm S.E.M. Statistical significance between more than two groups was tested using one-way ANOVA and a multiple post hoc test (LSD). The significance was set at $P<0.05$. The results are represented as mean $\pm \mathrm{SD}$.

\section{Results}

Three mortality were observed in Group 2 (week 4), Group 6 (week 4), and Group 7 (week 10). The overall survival rate was $92.85 \%$.

\section{1. Body weight changes:}

Relatively more weight losses were observed in the group $2(353.05 \pm 17.32)$ and Group 3 showed less decrease in body weight $(405.28 \pm 13.7)$ as compared with group $1(444.13 \pm 39.5)$. In case of group 4 , there was significant increase in the body weight $(426.02 \pm 11.32)$ as compared to group 2 . The group 7 showed the body weight significantly increased $(395.05 \pm 20.10)$ when compared to group 2 and group 6 showed significant (413.37 \pm 15.73$)$ improved in body weight were noticed.

\section{III.2. Hematological Analysis:}

Hematological and serum variables for DEN-treated and control rats are shown in (Figure 1-6).

Hemoglobin concentration was significantly lower in rats of groups 3 and $5(7.43 \pm 0.46$ and $8.22 \pm 0.139)$ respectively when compared to the animals of groups 1 and $4(13.00 \pm 0.353$ and $14.2 \pm 0.75)(\mathrm{p}<0.001)$. No significant changes were observed in total leukocyte counts. The mean neutrophils count in the all groups was decreased significantly $(\mathrm{P}<0.001)$ except in the animals of group 4, as compared to the animals of group 1.The mean RBC count in the animals of the groups 1,2 , and 6 were $9.66 \pm 0.22,8.18 \pm 0.08$ and $6.840 \pm 0.0927$ $10^{6} / \mathrm{mm}^{3}$ respectively. The RBC count of the groups 4 and 6 was significantly higher than that of the animals of groups 2 and $7(\mathrm{P}<0.001)$.

\section{III.3. Antioxidant Status:}

In this study, malondialdehyde (MDA) levels are a direct indicator of lipid peroxidation and they were observed to be significantly decreased after DEN treatment $(P<0.001)$. Se control treatment of normal rats did not indicate any changes in MDA levels. DEN treatment to animals resulted in a significant decrease $(P<$ 
$0.001)$ in the enzymes activities of GST, SOD, catalase and GPx. In contrast, a significant increase $(P<0.01)$ in the levels of GSH was observed following DEN treatment (Table 2). However, SMX +Se treatment to DEN treated animals resulted in a significant elevation in the activities of enzymes GST, catalase, GPx and SOD, but caused a significant decrease $(P<0.001)$ in the levels of GSH when compared with DEN treated group. (Table 1)

\section{Discussion}

Figure 2-6 shows the levels of hemoglobin, TLC, Neutrophils count, Lymphocytes count and RBC count in the control and experimental groups of rats. Increased RBC, hemoglobin level in the animals of group 4 indicated the protective effects of selenium (sodium selenite) on the hemopoietic system. The maximum recovery was observed in many of the hematological parameters (Hemoglobin, RBC and TLC) in the group of 6 . The blood cells are the mobile units of the body's protective system ${ }^{32}$. Increased total leukocyte count $(\mathrm{p}<0.01)$ in the animals of group 2 indicate decreased resistance of the body to toxicity induced by DEN. Decreased RBC count $(p<0.001)$, hemoglobin $(p<0.01)$ also indicate the severity of hepatic damage induced by DEN. Decrease in the hemoglobin levels might be due to increased catabolism and degradation of hemoglobin. Reduction in hemoglobin content can be related to decrease in RBC number which in turn indicates anemic induction ${ }^{33-34}$. Induction of anemic status in toxicity and HCC cancer are well established. Increased RBC and WBC contents (neutrophils and lymphocytes) and increased levels of hemoglobin in the drug treated group 6 along with the toxin DEN indicate the protective effect of the combination SMX + Se on the hemopoietic system.

Neutrophils are the major granulocytes to be activated when the body gives the response to any antigen and they provide the first line of defense. In the animals of group 2, neutrophils was increased significantly $(\mathrm{P}<0.001)$ as compared to the animals of group 1. It is also clear that the increase level of neutrophils in DEN group is the result of release of inflammation mediators in to the blood.

The protective effects of selenium on the oxidative stress enzymes were observed in an experimental model of DEN-induced liver carcinogenesis. The study clearly indicates that the administration of selenium attenuates the DEN induced alterations in the levels of lipid peroxidation and the overall antioxidant enzymatic status in the rat liver.

In the present study, the levels of lipid peroxidation in the hepatic tissues were decreased after 22 week of DEN treatment. Previous studies have shown reduced rates of lipid peroxidation in the tumor tissue of various types of cancers ${ }^{35-38}$. Our results indicate that a decrease in the levels of MDA can be attributed to increased cell proliferation, which is thought to be involved in the pathogenesis of liver cancer. Cancer cells acquire particular characteristics that promote their proliferation ${ }^{39}$ and tend to proliferate faster when the lipid peroxidation level is low. Therefore, the decreased lipid peroxidation observed in DEN-treated rats could be due to increased cell proliferation. The malignant tissues seem to be less susceptible and more resistant to free radical attack, and hence lipid peroxidation is less intense ${ }^{40}$. Interestingly, simultaneous SMX+Se treatment to DEN treated animals showed an increase in the levels of MDA. The observed increased levels of LPO under $\mathrm{SMX}+\mathrm{Se}$ treatment could be as a consequence of the inhibitory action of selenium on the proliferative activity of cancerous cells. Aerobic cells are endowed with extensive antioxidant defense mechanisms including both low molecular weight scavengers, which counteract the damaging effects of toxic oxygen species ${ }^{41-42}$ and endogenous antioxidant enzyme such as superoxide dismutase (SOD) which converts the superoxide free radical anion to hydrogen peroxide. Our studies have also shown reduced catalase levels in DEN treated rats. The reduction in catalase level correlated well with tumor stage according to Dukes, suggesting that this peroxisomal enzyme could be used as a potential prognostic marker ${ }^{43}$. Besides, enhanced GSH level was also observed following DEN treatment. This might be due to the increased cell proliferation involved in the pathogenesis of DEN-induced liver cancer ${ }^{44}$. It was previously demonstrated that GSH is expressed in greater amounts in the neoplastic cells, conferring a selective growth advantage ${ }^{45}$. Thus, the elevated GSH levels observed in our study might be used as a marker of cell proliferation. The antioxidant enzymes SOD, GPx and catalase limit the effects of oxidant molecules on tissues and are activated in the defense against oxidative cell injury by means of their being free radical scavengers ${ }^{46}$. In the present study, SOD, GPx and catalase activities were found to be significantly decreased following DEN treatment, when compared to the animals of the normal control (group 1).The antioxidant activity of selenium can be explained by its important role in preventing lipid peroxidation and in protection of integrity and functioning of tissues and cells. This mechanism has been well documented to be important for the chemopreventive activity of many thiol-reactive chemopreventive agents ${ }^{47-49}$. The ability of selenium compounds to inhibit growth and induce tumor cell apoptosis has been suggested to be a potential mechanism for cancer chemoprevention. ${ }^{50}$

\section{Conclusion}


In conclusion, the result of this study suggests that sulfamethoxazole + selenium has a positive beneficial effect against the chemically induced hepatocarcinogenesis in rats, which provides an effective chemopreventive combination approach to manage the disease. However, further studies are warranted with regard to other bioassays and documentation of specific molecular markers to establish the exact mechanism for sulfamethoxazole + selenium mediated chemoprevention of cancer. Moreover further exploration of the combination is required to be done by the researchers in terms of other carcinoma.

\section{Reference}

[1]. World Health Organization. The Global Burden of Disease: 2004 Update. Geneva: World Health Organization; 2008.

[2]. Motola-Kuba D, Zamora-Valdes D, Uribe M, Mendez-Sanchez N. Hepatocellular carcinoma. An overview. Ann. Hepatol. 2006;5:16-24.

[3]. Kumar R. Saraswat M.K, Sharma B.C, Sakhuja. P and Sarin S.K. Characteristics of hepatocellular carcinoma in India: a retrospective analysis of 191 cases. Q J Med. doi:10.1093/qjmed/hcn033.

[4]. Annual Report 1987. National Cancer Registry Programme. New Delhi, Indian Council of Medical Research, 1990.

[5]. Jayant K, Rao RS, Nene BM, Dale PS. Rural Cancer Registry at Barshi- Report 1988-92. Barshi, Rural Cancer Registry, 1994.

[6]. Kolaja KL, Klaunig JE. Vitamin E modulation of hepatic focal lesion growth in mice. Toxicol. Appl. Pharmacol. 1997;143:380387.

[7]. Qi YT, Chen X, Chan CY, et al. Two-dimensional differential gel electrophoresis/analysis of diethylnitrosamine induced rat hepatocellular carcinoma. Int. J. Cancer. 2008;122:2682-2688.

[8]. Kawanishi S, Hiraku Y, Murata M, Oikawa S. The role of metals in site-specific DNA damage with reference to carcinogenesis. Free Radic. Biol. Med.2002;32:822-832.

[9]. Valko M, Rhodes CJ, Moncol J, Izakovic M, Mazur M. Free radicals, metals and antioxidants in oxidative stress-induced cancer. Chem. Biol. Interact.2006;160:1-40.

[10]. Philip A. Masters, Thomas A. O’Bryan et al. Trimethoprim-Sulfamethoxazole revisited. Arch Intern Med 2003; 163: 402-410.

[11]. Rieder, M. J., Uetrecht, J., Shear, N. H., Cannon, M., Miller, M., and Spielberg, S. P. Diagnosis of sulfonamide hypersensitivity reactions by in-vitro 'rechallenge' with hydroxylamine metabolites. Ann. Intern. Med. 1989; 110: $286-289$.

[12]. Leeder, J. S., Nakhooda, A., Spielberg, S. P., and Dosch, H. M. Cellular toxicity of sulfamethoxazole reactive metabolites.II. Inhibition of natural killer activity in human peripheral blood mononuclear cells. Biochem. Pharmacol 1991; 41: 575-583.

[13]. National Research Council. Food and nutrition board recommended dietary allowances, 10th ed. Washington, DC: National Academy Press; 1989.

[14]. Combs Jr. GF, Gray WP. Chemopreventive agents: selenium. Pharmacol Ther 1988;79:179-92.

[15]. Neve J. Selenium as a risk factor for cardiovascular diseases. J Cardiovasc Risk 1996;3:42-7.

[16]. Heliovaara M, Knekt P, Aho K, Aaran RK, Alfthan G, Aromaa A. Serum antioxidants and risk of rheumatoid arthritis. Ann Rheum Dis 1994;53:51-3.

[17]. Look MP, Rockstroh JK, Rao GS, Kreuzer KA, Spengler U, Sauerbruch T. Serum selenium versus lymphocyte subsets and markers of disease progression and inflammatory response in human immunodeficiency virus-1 infection. Biol Trace Elem Res 1997;56(1):31-41.

[18]. Combs Jr. GF, Clark LC, Turnbull BW. Reduction of cancer risk with an oral supplement of selenium. Biomed Environ Sci 1997; 10:227-34.

[19]. Allan BC, La courciere GM, Stadtman TC (1999) Responsiveness of selenoproteins to dietary selenium. Annu Rev Nutr 19:1-16.

[20]. Taylor PR, Parnes HL, Lippman SM (2004) Science peels the onion of selenium effects on prostate carcinogenesis. J Natl Cancer Inst 96:645-647.

[21]. Alwahaibi N, Mohamed J, Alhamadani A (2010) Supplementation of selenium reduces chemical hepatocarcinogenesis in male Sprague-Dawley rats. J Trace Elem Med Biol 24:119-123.

[22]. Ghosh A S et al. Effect of DENA induced hepatocarcinogenesis on neuroendocrine levels in male rats. Indian Journal of Exp. Biolog 2008; 46: 498-504.

[23]. Lawrence D. Mayer, Troy O. Harasym, Paul G. Tardi, et al. Ratiometric dosing of anticancer drug combinations: Controlling drug ratios after systemic administration regulates therapeutic activity in tumor-bearing mice. Mol Cancer Ther 2006; 5:1854-1863.

[24]. Plaa GL, Hewitt WR (1989) Detection and evaluation of chemically induced liver injury. In: Wallace Hyes A (ed) Principle and methods of toxicology, 2nd edn. Raven, New York, p 399.

[25]. Wills ED. Mechanisms of lipid peroxide formation in animal tissues. Biochem J. 1966;99:667-676.

[26]. Paglia DE, Valentine WN. Studies on the quantitative and qualitative characterization of erythrocyte glutathione peroxidase. J Lab Clin Med. 1967;70:158-169.

[27]. Kono Y. Generation of superoxide radical during autoxidation of hydroxylamine and an assay for superoxide dismutase. Arch Biochem Biophys. 1978;186:189-195.

[28]. Luck H. Quantitative determination of catalase activity of biological material. Enzymologia.1954;17:31-40.

[29]. Habig WH, Pabst MJ, Jakoby WB. Glutathione S-transferases. The first enzymatic step in mercapturic acid formation. J Biol Chem. 1974;249:7130-7139.

[30]. Ellman GL. Tissue sulfhydryl groups. Arch Biochem Biophys. 1959;82:70-77.

[31]. Carlberg I, Mannervik B. Glutathione reductase. Methods Enzymol. 1985;113:484-490.

[32]. Guyton A.C., and J.E. Hall, 1991. Text book of medical physiology, 10th edition WB Saunder's Company, Philadelphia PA.

[33]. Sarantchandra, G, J. Chandre, S. Jayasuder and P.B.Murthy 1996. Toxicology of cleistanthus collinus an indigeneous plant acute toxicity study Indian J. Toxicol.3: 9-17.

[34]. Murrary-Iyon, I.M., 1983. Primary and secondary causes of the liver. In: carcinoma of the liver, billiary tract and pancrease, Genet J.C (ed). Edward, Arnold Ltd. Bed for square, London.

[35]. Tanaka T. Effect of diet on human carcinogenesis. Crit Rev Oncol Hematol. 1997;25:73-95.

[36]. Tanaka T, Kawabata K, Kakumoto M, Hara A, Murakami A, Kuki W, Takahashi Y, Yonei H, Maeda M, Ota T, et al. Citrus auraptene exerts dose-dependent chemopreventive activity in rat large bowel tumorigenesis: the inhibition correlates with suppression of cell proliferation and lipid peroxidation and with induction of phase II drug-metabolizing enzymes. Cancer Res. 1998;58:2550-2556. 
[37]. Dani V, Goel A, Vaiphei K, Dhawan DK. Chemopreventive potential of zinc in experimentally induced colon carcinogenesis. Toxicol Lett. 2007;171:10-18.

[38]. Cheeseman KH, Collins M, Proudfoot K, Slater TF, Burton GW, Webb AC, Ingold KU. Studies on lipid peroxidation in normal and tumour tissues. The Novikoff rat liver tumour. Biochem J.1986;235:507-514.

[39]. Schmelz EM, Sullards MC, Dillehay DL, Merrill AH Jr. Colonic cell proliferation and aberrant crypt foci formation are inhibited by dairy glycosphingolipids in 1, 2-dimethylhydrazine-treated CF1 mice. J Nutr. 2000;130:522-527.

[40]. Nakagami K, Uchida T, Ohwada S, Koibuchi Y, Morishita Y. Increased choline kinase activity in 1,2-dimethylhydrazine-induced rat colon cancer. Jpn J Cancer Res. 1999;90:1212-1217.

[41]. Halliwell B, Gutteridge JMC. Free radicals in biology and medi-cine, 2nd edition, Clarendon press, Oxford 1989 ; $188-276$.

[42]. Mukerjee PK. GMP for Indian system of medicine. In: GMP for Botanicals- regulatory and quality issues on phytomedicines, Mukerjee PK, Verpoorte R (ed): Business Horizons: New Delhi, India; 2003: 99-112.

[43]. Cablé S, Keller JM, Colin S, Haffen K, Kédinger M, Parache RM, Dauça M. Peroxisomes in human colon carcinomas. A cytochemical and biochemical study. Virchows Arch B Cell Pathol Incl Mol Pathol.1992;62:221-226.

[44]. Cao G, Sofic E, Prior RL. Antioxidant and prooxidant behavior of flavonoids: structure-activity relationships. Free Radic Biol Med. 1997;22:749-760.

[45]. Obrador E, Navarro J, Mompo J, Asensi M, Pellicer JA, Estrela JM. Glutathione and the rate of cellular proliferation determine tumour cell sensitivity to tumour necrosis factor in vivo. Biochem J.1997;325(Pt 1):183-189.

[46]. Nijhoff WA, Peters WH. Induction of rat hepatic and intestinal glutathione S-transferases by dietary butylated hydroxyanisole. Biochem Pharmacol. 1992;44:596-600.

[47]. Kyle ME, Miccadei S, Nakae D, Farber JL. Superoxide dismutase and catalase protect cultured hepatocytes from the cytotoxicity of acetaminophen. Biochem Biophys Res Commun. 1987;149:889-896.

[48]. Matés JM, Sánchez-Jiménez F. Antioxidant enzymes and their implications in pathophysiologic processes. Front Biosci. 1999;4:D339-D345.

[49]. Talalay P, Fahey JW. Phytochemicals from cruciferous plants protect against cancer by modulating carcinogen metabolism. J Nutr. 2001;131:3027S-3033S.

[50]. Posner GH, Cho CG, Green JV, Zhang Y, Talalay P. Design and synthesis of bifunctional isothiocyanate analogs of sulforaphane: correlation between structure and potency as inducers of anticarcinogenic detoxication enzymes. J Med Chem. 1994;37:170-176.

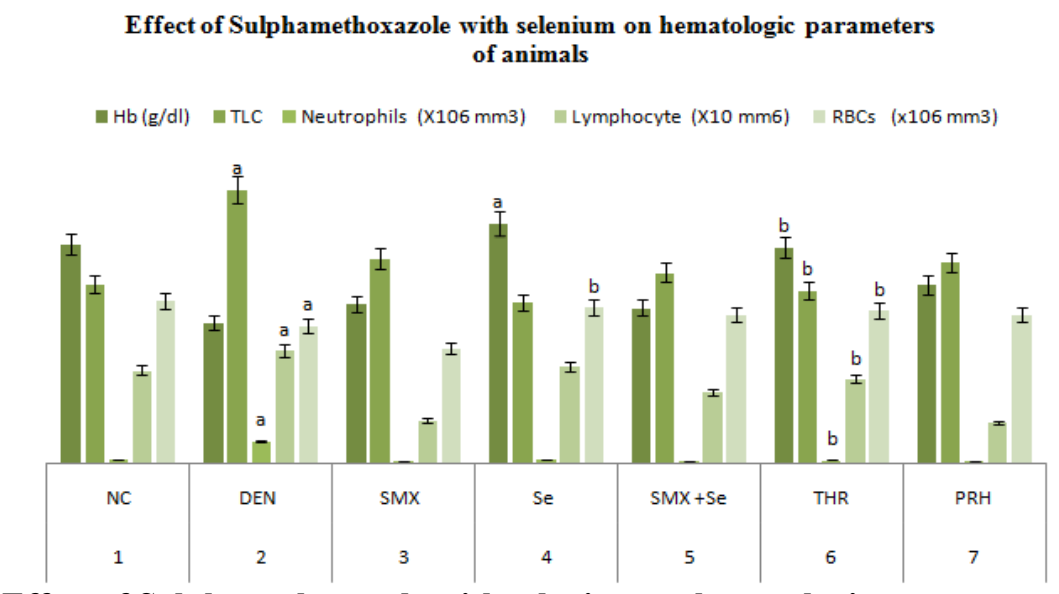

Figure 1: Effect of Sulphamethoxazole with selenium on hematologic parameters of animals Mean \pm S.E.M., $\mathrm{n}=6$; one way ANOVA followed by multiple post hoc test.

$\mathrm{NC}(0.9 \%$ saline p.o.), DEN (Diethylenitrosamine, $150 \mathrm{mg} / \mathrm{kg}$ i.p.), SMX (Sulphamethoxazole, $30 \mathrm{mg} / \mathrm{kg}$ p.o.) $\mathrm{Se}$ (Sodium selenite $4 \mathrm{mg} / \mathrm{kg}$ p.o.), SMX+Se (Sulphamethoxazole+ Sodium selenite, $30 \mathrm{mg} / \mathrm{kg}+4 \mathrm{mg} / \mathrm{kg}$ p.o.) ${ }^{\mathrm{a}} \mathrm{p}<0.05$ normal versus disease control animals, ${ }^{\mathrm{b}} \mathrm{p}<0.001$ disease control versus treated animals

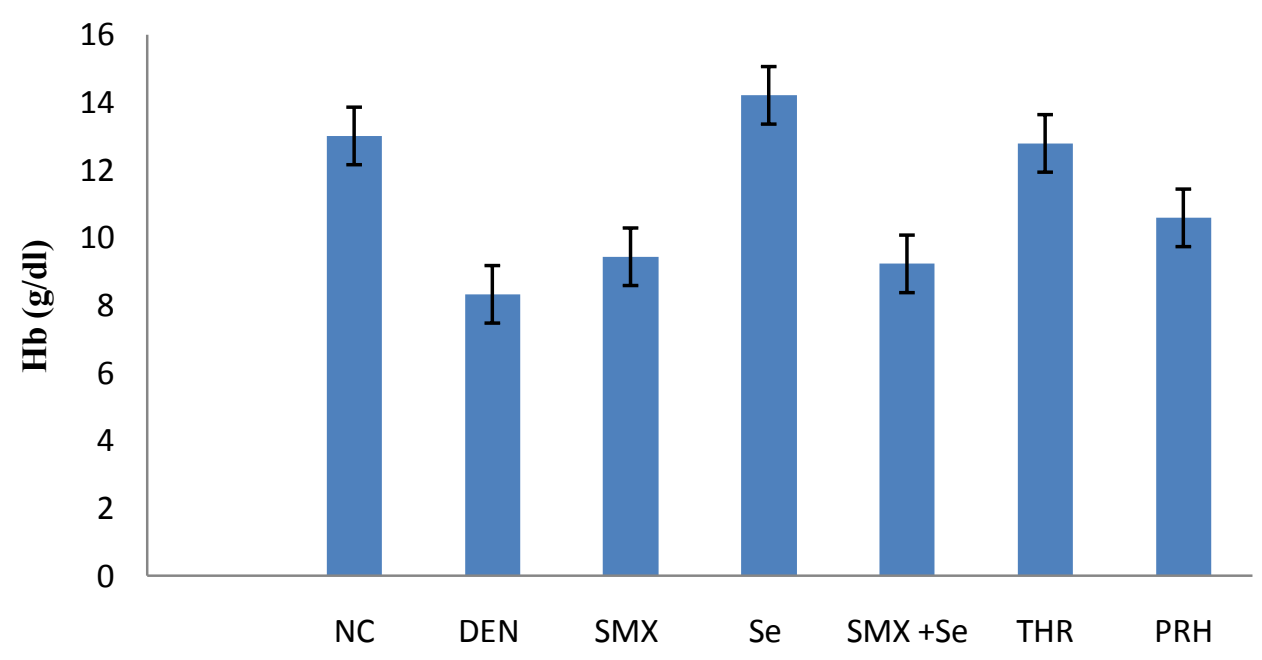


Figure 2: Effect of Sulphamethoxazole with selenium on hemoglobin of animals Mean \pm S.E.M., $\mathrm{n}=6$; one way ANOVA followed by multiple post hoc test.

NC (0.9\% saline p.o.), DEN (Diethylenitrosamine, $150 \mathrm{mg} / \mathrm{kg}$ i.p.), SMX (Sulphamethoxazole, $30 \mathrm{mg} / \mathrm{kg}$ p.o.) $\mathrm{Se}$ (Sodium selenite $4 \mathrm{mg} / \mathrm{kg}$ p.o.), SMX+Se (Sulphamethoxazole+ Sodium selenite, $30 \mathrm{mg} / \mathrm{kg}+4 \mathrm{mg} / \mathrm{kg}$ p.o.)

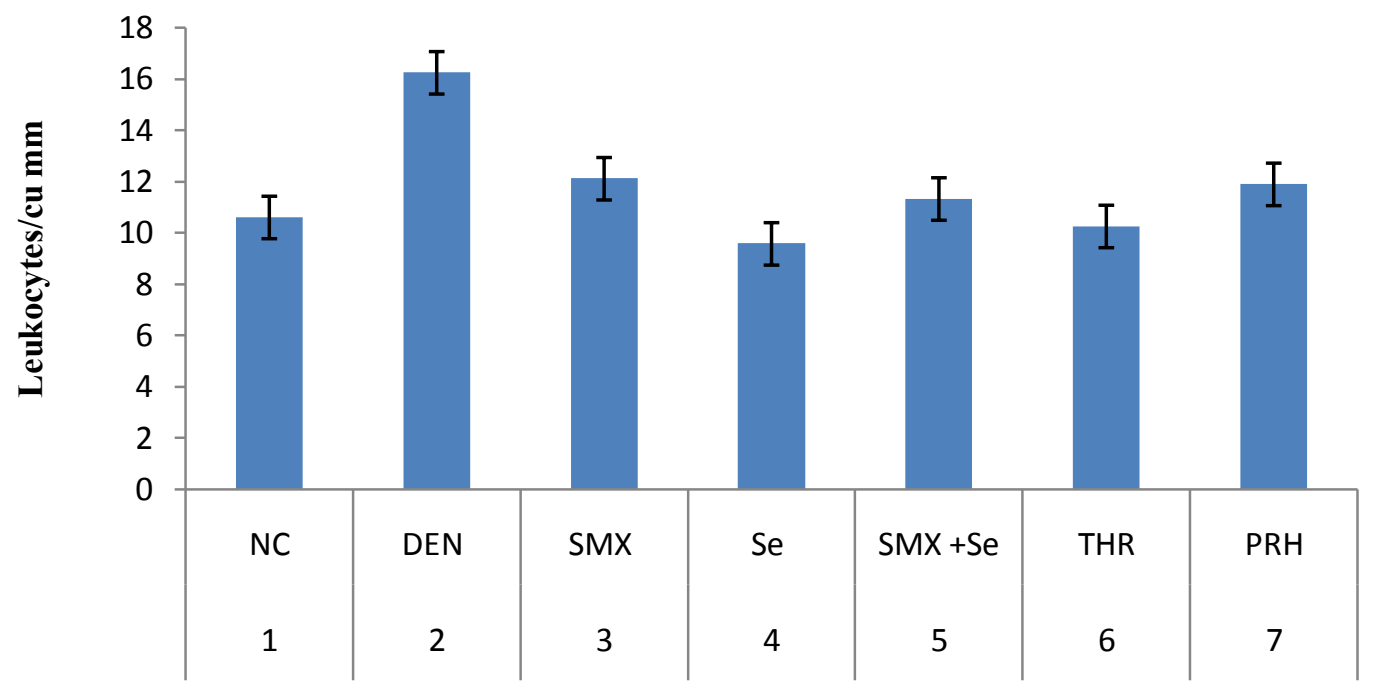

Figure 3: Effect of Sulphamethoxazole with selenium on total leukocytes count of animals Mean \pm S.E.M., $\mathrm{n}=6$; one way ANOVA followed by multiple post hoc test.

NC (0.9\% saline p.o.), DEN (Diethylenitrosamine, $150 \mathrm{mg} / \mathrm{kg}$ i.p.), SMX (Sulphamethoxazole, $30 \mathrm{mg} / \mathrm{kg}$ p.o.) $\mathrm{Se}$ (Sodium selenite $4 \mathrm{mg} / \mathrm{kg}$ p.o.), SMX+Se (Sulphamethoxazole+ Sodium selenite, $30 \mathrm{mg} / \mathrm{kg}+4 \mathrm{mg} / \mathrm{kg}$ p.o.)

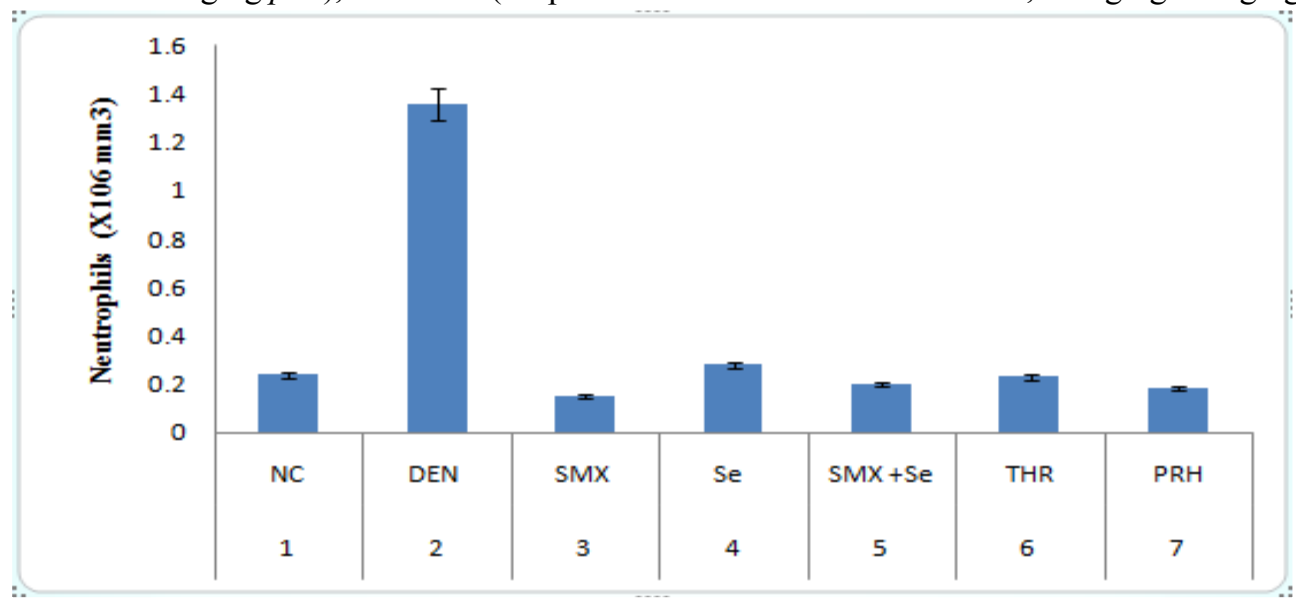

Figure 4: Effect of Sulphamethoxazole with selenium on Neutrophils count on animals NC (0.9\% saline p.o.), DEN (Diethylenitrosamine, $150 \mathrm{mg} / \mathrm{kg}$ i.p.), SMX (Sulphamethoxazole, $30 \mathrm{mg} / \mathrm{kg}$ p.o.) Se (Sodium selenite $4 \mathrm{mg} / \mathrm{kg}$ p.o.), SMX+Se (Sulphamethoxazole+ Sodium selenite, $30 \mathrm{mg} / \mathrm{kg}+4 \mathrm{mg} / \mathrm{kg}$ p.o.) 


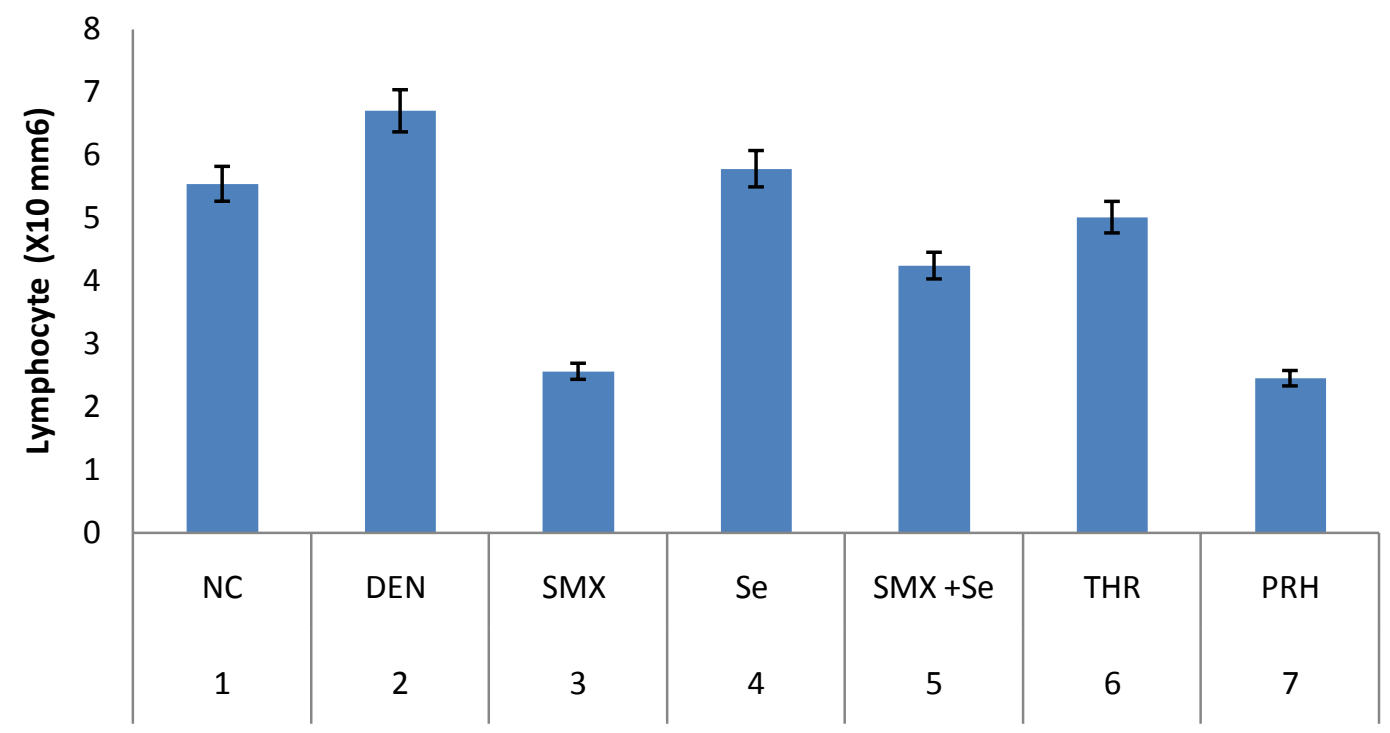

Figure 5: Effect of Sulphamethoxazole with selenium on lymphocyte count of animals Mean \pm S.E.M., $\mathrm{n}=6$; one way ANOVA followed by multiple post hoc test.

NC ( $0.9 \%$ saline p.o.), DEN (Diethylenitrosamine, $150 \mathrm{mg} / \mathrm{kg}$ i.p.), SMX (Sulphamethoxazole, $30 \mathrm{mg} / \mathrm{kg}$ p.o.) Se (Sodium selenite $4 \mathrm{mg} / \mathrm{kg}$ p.o.), SMX+Se (Sulphamethoxazole+ Sodium selenite, $30 \mathrm{mg} / \mathrm{kg}+4 \mathrm{mg} / \mathrm{kg}$ p.o.)

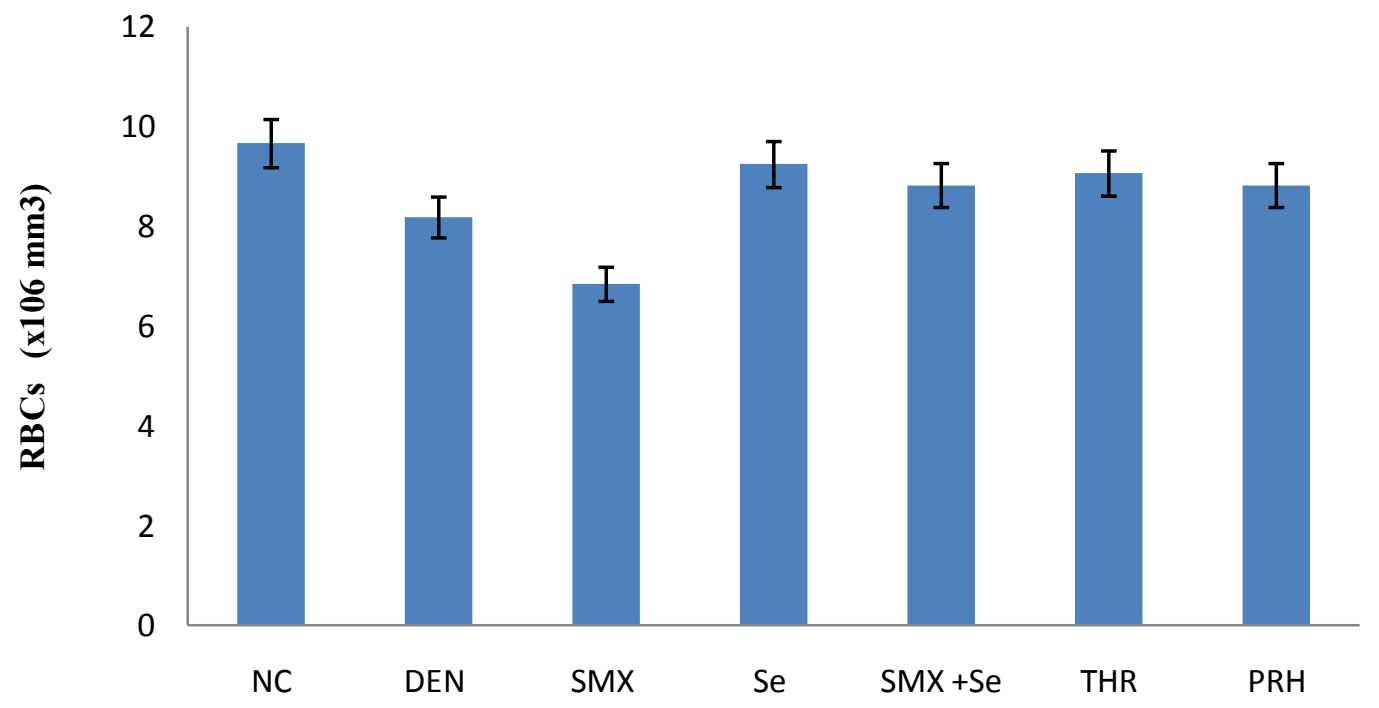

Figure 6: Effect of Sulphamethoxazole with selenium on RBC count of animals Mean \pm S.E.M., $\mathrm{n}=6$; one way ANOVA followed by multiple post hoc test.

NC ( $0.9 \%$ saline p.o.), DEN (Diethylenitrosamine, $150 \mathrm{mg} / \mathrm{kg}$ i.p.), SMX (Sulphamethoxazole, $30 \mathrm{mg} / \mathrm{kg}$ p.o.) Se (Sodium selenite $4 \mathrm{mg} / \mathrm{kg}$ p.o.), SMX+Se (Sulphamethoxazole+ Sodium selenite, $30 \mathrm{mg} / \mathrm{kg}+4 \mathrm{mg} / \mathrm{kg}$ p.o.) 
Table 1. Effect of Sulfamethoxazole + selenium on lipid peroxidation and antioxidant enzymes in the liver of rats subjected to $22 \mathrm{wk}$ of DEN treatment

\begin{tabular}{|c|c|c|c|c|c|c|}
\hline S.no & Groups & $\begin{array}{l}\text { LPO (nmoles } \\
\text { of } \\
\text { MDA/min/100 } \\
\text { mg protein) }\end{array}$ & $\begin{array}{l}\text { CAT } \\
\text { (mmol of } \\
\mathrm{H}_{2} \mathrm{O}_{2} \text { decom } \\
\text { posed/min/mg } \\
\text { protein) }\end{array}$ & SOD (I.U) & $\begin{array}{l}\text { GPx }(\mathrm{mmol} \\
\text { NADPH } \\
\text { oxidized } / \mathrm{min} / \mathrm{m} \\
\text { g protein) }\end{array}$ & $\begin{array}{l}\text { GSH }(\mu \mathrm{mol} \mathrm{GSH} / \mathrm{g} \\
\text { tissue) }\end{array}$ \\
\hline 1 & $\mathrm{NC}$ & $3.21 \pm 0.38$ & $1.24 \pm 0.200$ & $6.45 \pm 0.617$ & $0.71 \pm 0.02$ & $0.63 \pm 0.011$ \\
\hline 2 & DEN & $2.24 \pm 0.35^{*}$ & $0.74 \pm 0.03^{*}$ & $4.45 \pm 0.36^{*}$ & $0.44 \pm 0.15^{*}$ & $1.09 \pm 0.03 *$ \\
\hline 3 & SMX & $2.34 \pm 0.23$ & $0.89 \pm 0.34$ & $4.89 \pm 0.65$ & $0.56 \pm 0.56$ & $0.98 \pm 0.43$ \\
\hline 4 & $\mathrm{Se}$ & $3.24 \pm 0.20$ & $1.24 \pm 0.13$ & $6.29 \pm 0.54$ & $0.72 \pm 0.05$ & $0.64 \pm 0.07$ \\
\hline 5 & $\begin{array}{l}\text { SMX } \\
+\mathrm{Se}\end{array}$ & $2.09 \pm 0.12$ & $0.99 \pm 0.11$ & $5.01 \pm 0.78$ & $0.60 \pm 0.14$ & $0.89 \pm 0.14$ \\
\hline 6 & THR & $3.01 \pm 0.21 \#$ & $1.23 \pm 0.28 \# * *$ & $5.67 \pm 0.47 \#$ & $0.65 \pm 0.17 \#$ & $0.65 \pm 0.07^{* \#}$ \\
\hline 7 & PRH & $2.99 \pm 0.32^{* *}$ & $1.01 \pm 0.54 \#$ & $5.14 \pm 0.34^{*}, \#$ & $0.63 \pm 0.26 \#$ & $0.78 \pm 0.45 \#$ \\
\hline
\end{tabular}

Mean \pm S.E.M., $\mathrm{n}=6$; one way ANOVA followed by multiple post hoc test.

NC ( $0.9 \%$ saline p.o.), DEN (Diethylenitrosamine, $150 \mathrm{mg} / \mathrm{kg}$ i.p.), SMX (Sulphamethoxazole, $30 \mathrm{mg} / \mathrm{kg}$ p.o.) Se (Sodium selenite $4 \mathrm{mg} / \mathrm{kg}$ p.o.), SMX+Se (Sulphamethoxazole+ Sodium selenite, $30 \mathrm{mg} / \mathrm{kg}+4 \mathrm{mg} / \mathrm{kg}$ p.o.) Significant at $* * P<0.05$ Normal control versus Disease control animal $* P<0.001$ Disease control versus treated animals \# $\mathrm{P}<0.001$ Disease control versus treated animals 